\title{
Fodder salt fed to small ruminants
}

\section{Gabriel Jorge Carneiro de Oliveira ${ }^{1}$, Soraya Maria Palma Luz Jaeger ${ }^{1}$, Adriana Regina Bagaldo $^{1}$, Paulo Andrade de Oliveira ${ }^{2}$}

\author{
${ }^{1}$ CCAAB/UFRB \\ 2 Mestrando em Ciência Animal CCAAB/UFRB
}

ABSTRACT - The price of the products used for animal supplementation and the existence of a rich native flora of eudicotyledon forage, drove the idea for develop a technique feed supplementation aiming improve livestock yield levels in the semiarid zone. The fodder salt technique has been developed by the Tropical Zootechnical Rsearch Group at the Centro de Ciências Agrárias Ambientais e Biológicas da Universidade Federal do Recôncavo da Bahia (CCAAB/UFRB). Defined as a mixture of mineral salt and ground eudocotyledon forage hay, among them, some xerophitas species, the”fodder salt” consisting to a low cost technique with high applicability potential for ruminant production in semiarid environment. The salt controls consumption, for it facilitates the offer of eudicotyledon hay. When added to the mixture, it becomes salty, and the animals ingest it slowly and repeatedly. This behavior results in a reduction of feed intake, in less fighting among animals, and allows a better even distribution of feed for all of them. The researches on "fodder salt" have presented satisfactory responses of animal performance, and without doubt, this technique facilitates feed management and increases herd yield.

Key Words: caatinga, forrage, livestock, semiarid, sustaintability

\section{Sal forrageiro para pequenos ruminantes}

RESUMO - O custo dos insumos utilizados na suplementação alimentar e a riqueza do semiárido em forrageiras eudicotiledoneas de bom valor nutritivo despertaram a idéia de desenvolver tecnologias adaptadas às condições tropicais semiáridas. O sal forrageiro é uma tecnologia que está sendo desenvolvida pelo grupo de pesquisa em Zootecnia Tropical (CNPq), do Centro de Ciências Agrárias Ambientais e Biológicas da Universidade Federal do Recôncavo da Bahia (CCAAB/UFRB). Definido como uma mistura de sal mineral com feno moído de forrageiras eudicotiledôneas, dentre elas algumas espécies vegetais xerófilas, o sal forrageiro consiste em uma tecnologia de baixo custo, com grande potencial de aplicação no sistema de produção de ruminantes. Nesta técnica, o sal é utilizado como controlador de consumo e, como tal, facilita sobremaneira o fornecimento do feno da eudicotiledônea, uma vez que sua presença na mistura a torna salgada, fazendo com que os animais realizem a ingestão do feno de forma lenta e repetida, evitando assim o consumo elevado da forrageira por todos ou alguns animais, as brigas entre eles e o consumo reduzido por outros indivíduos. Os trabalhos de pesquisa com sal forrageiro têm apresentado respostas satisfatórias no desempenho dos animais, e, sem dúvida, esta técnica facilita o manejo alimentar do rebanho.

Palavras-chave: caatinga, forragem, pecuária, semiárido, sustentabilidade

\section{Introduction}

The caatinga landscape comprises a variety of ecological sites with different levels of forage yield. The species density, frequency and dominance depend on pluviosity, topography and soil.

The above statement also defines the Brazilian semiarid environment, which is located in the Northeast region of the country, with the exception of the semiarid zone of Minas Gerais state that is part of the Southeast region. At the same time, our initial definition clarifies a fact often forgotten, namely the existence of different environments within the semiarid area: each caatinga is unique.
The most influential factor in terms of caatinga diversity is the pluviometry, in spite of its variability among and between years. Soil fertility, which ranges from very rich to very poor, as well as topography, are also factors that influence variation, although with less intensity. In general terms, we can distinguish two semiarid macro ecosystems: one near the coast, with two rainy seasons per year (thunder and winter); and the other closer to the cerrado, with only one rainy season (thundering) from October to March.

Inspite of those differences, the semiarid zone, as a whole, has some constant features:

I-The native vegetation is rich in eudicotyledons with

Corresponding author:gajocaol@yahoo.com.br 
high forage value. It is probably the planet's richest region in terms of tree and shrub forage

Phytomass production of tree and shrub forages may be higher than the exotic forage production. Despite the higher yield of exotic forages at soil level, the tree and shrub forages form a canopy with a wider area than the soil occupied by their stems. Thus, its phytomass production is proportional to the crown volume and not to the occupied area. In other words, tree and shrub forages "vertical" pasture (that rises from the ground) yield might be higher than the "horizontal" forage produced on the soil surface by exotic grass forage (Oliveira et al., 2004). Oliveira et al. (2009), in a study involving 5 native forage species from the semiarid zone, found the following production mean values: Manihot pseudoglaziovi (maniçoba) $122.49 \mathrm{~kg} / \mathrm{DM} / \mathrm{m}^{2}$, Syagrus coronata (ouricuri) $117.46 \mathrm{~kg} / \mathrm{DM} / \mathrm{m}^{2}$, Cereus jamacaru (mandacaru) $89.63 \mathrm{~kg} / \mathrm{MS} / \mathrm{m}^{2}$, Cnidoscalus phyllacanthus (faveleira) $98.133 \mathrm{~kg} / \mathrm{DM} / \mathrm{m}^{2}$ and Cróton conduplicatus (quebra-facão) $58.90 \mathrm{Kg} / \mathrm{DM} / \mathrm{m}^{2}$. The authors report that Cenchrus ciliaris (buffel grass), an exotic grass forage originary from Africa, capable of increasing the forage disponibility per hectare in the caatinga, presents a much lower dry matter yield per $\mathrm{m}^{2}$ than the observed yield in tree and shrub forages, with a mean yield of $1.2 \mathrm{~kg} / \mathrm{DM} / \mathrm{m}^{2}$. This fact proves that the dry matter production per $\mathrm{m}^{2}$ of tree and shrub forages, i.e vertical pasture, is higher than the horizontal pasture yield generated by exotic grass pasture.

Those results confirmed our observations and raised the interest of the Tropical Zootechnical research group of using those forages to develop technologies adapted to semiarid tropical conditions.

\section{Dry season}

Pluviometry and rainfall distribution, which is highly irregular within and among years, make the rational exploration of caatinga more difficult. Furthermore, the caatinga is a fragile environment even for husbandry. According to Oliveira et al. (2004), one of the most serious misunderstandings when rearing small ruminants is the lack of adequacy in terms of soil carrying capacity. This happens due to the widespread information that you can rear an animal of $450 \mathrm{~kg}$ live weight (LW), you can also rear nine animals of $50 \mathrm{~kg} \mathrm{LW}$. An animal weighting $450 \mathrm{~kg}$ has a metabolic weight (MW) of $97.79 \mathrm{~kg}$, while the MW of an animal weighting $50 \mathrm{~kg} \mathrm{LW}$ is $18.80 \mathrm{~kg}$, which means that where an animal of $450 \mathrm{~kg}$ is reared, one should rear no more than 5 of $50 \mathrm{~kg}$. Furthermore, the author states that the continuous and excessive animal loading (over grazing) in semiarid conditions is one of the main factors causing pasture degradation and acceleration of desertification processes, which reduce even more the forage production potential and consequently the support capacity of the property.

Besides the support capacity, animal production in semiarid conditions requires the partial or full use at least of six techniques for economic and social success, as well as for the sustainability of the productive system.

Briefly, the six techniques are:

\section{1 - Appropriate pasture formation}

According to Oliveira et al. (2002), tillage handling techniques in the semiarid zone are not appropriate, for not being considered the richness of native eucotyledons with forage value, which play an important role in terms of yield. Hence, during soil tillage for pasture establishment, only plants with no forage value or function should be eliminated, whenever possible.

Besides phytomass production, tree and shrub forages: 1) offer shade, which is a relevant factor in tropical and semiarid conditions, for it improves the animals' confort and allows them to graze even during the hottest hours of the day. Therefore, shade has a positive effect on yield; 2) allow the recycling of mineral elements from the deepest soil layers to the surface (mainly through leaves and fruits), which improves or maintains soil fertility and increases pasture yield and support capacity; 3) reduces erosion due to the decrease in raindrop impact and to a more efficient fixation of water through the roots, thus improving soil conservation and management; 4) offer refuge for fauna, including predators of plagues, by creating a food-rich environment suitable for the reproduction of wild animals (Oliveira et al., 2002), thus enabling the sustainability of the system.

Pasture formation in the caatinga includes the introduction of exotic forages associated with native species with forage potential. Native forage populations and distribution must be controlled to avoid economic damage through reduction of the exotic grass pasture yield, or through reduction of dry matter production of the pasture as a whole (Oliveira et al., 2004).

Browsing is essential for the survival, development and production of hairy sheep and goats in the Brazilian semiarid zone. Monocotyledons have a diffuse root system (surface roots), and as they are the first plants to complete the biological cycle or dry, their nutritional value is reduced. On the other hand, dicotyledons have dominant primary roots (deep roots) and are able to look for water and other 
nutrients deeper into the soil. Hence they remain green for longer periods of time and maintain a higher nutritive value during the dry season (Oliveira et al., 2002).

Along the years, the replication of models imported from other ecosystems has caused serious problems to farmers and resulted in failed attempts to rear sheep and goats in the semiarid region (Oliveira et al., 2004). Still according to Oliveira et al. (2004), the production of small ruminants with good yield requires production models that are or can be adjusted to the environmental characteristics and to the peculiarities of each rural producer/property.

In the Brazilian semiarid region, native pastures prevail over cultivated pastures, except in the North of Minas Gerais (Giulietti et al., 2004). The native tree and shrub Caatinga have a very low animal performance rate which turn the pastoral activity unfeasible for commercial enterprises. Nevertheless, it is traditionally practiced by producers within a subsistence economy.

\section{2 - Pasture rotation}

The yearly interdiction of part of the rural property, until the recovery of the exotic monocotyledon forages, allows the eudicotyledons, among them several species of native grass forage, to complete their life cycle and to produce seeds. This fosters the sustainability of the pasture as a whole, and of the perennial forage with longer biological cycles, which is relevant in tropical pastures because they increase the grass yield and improve de nutritive value of the pasture as a whole due to higher nutritional value.

As pasture rotation in the caatinga environment must be done during the rainy season, when the support capactity is high, the interdicted pasture becomes a feed reserve for the dry season. Obviously, this technique can not be always applied. In years with uneven rainfall distribution or with no rainfall at all, pasture rotation is not feasible.

\section{3 - Fluctuating and variable animal population}

It is known that forage production in the semiarid region is very high during the rainy season and very low or inexistent during the dry season. This fact must be taken into account when deciding how many animals can be raised in a property within a year (fluctuating population) or between years (variable population).

It is evident that more animals can be reared during the rainy season than during the dry season. Thus some animals must be sold at the beginning of drought, or the herd must be reduced in very dry years. This reduction allows a higher yield per animal which may result in a higher production activity when compared to the production obtained with the maintainance of a fixed animal population.

The majority of producers insists on keeping the same amount of animals during drought and have to face the lack of forage and the consequent reduction of livestock performance, if not death.

\section{4 - Adjustment reserves}

As forage production is not constant along the year, it is necessary to stock feed to be offered to the animals during periods of quantitative and qualitative forage reduction. What it can be defined as adjustment reserve is normally called strategic reserve.

According to Oliveira et al. (2002) to maintain the herds without a dramatic yield reduction it is necessary to form a feed reserve when there is a surplus of forage (rainy season) that can be offered to the animals when there is feed shortage (dry season).

\section{5 - Strategic reserves}

Strategic reserves are forage reserves that are only used during the most critical years, when all the previous planning is unable to keep up with the feed demand of the property. The forage species most frecuently used as a strategic reserve belong to the cactaceae family: Cereus jamacaru and Opuntia fícus-indica Mill., as well as hay production from various forages.

It is important to state that, even applying all the above mentioned techniques, animal production in tropical conditions is characterized by low yield. And in semiarid conditions it is in economic terms a high-risk activity, which can result in income reduction or even bankruptcy.

\section{6 - Feed supplementation}

This is the dream technique. Without any doubt, this is, together with the other techniques mentioned before, the one that could solve the problems related to animal production. The main problem of feed supplementation is the cost and sometimes also its commercial availability.

Considering the prize of the products used for animal supplementation, the need of feed supplementation to improve livestock yield levels in the semiarid zone, and the existence of a rich native flora of eudicotyledon forage we developped a technique which could be easily applied in the semiarid zone by small and large producers.

The Brazilian largest sheep and goat populations are located in the semiarid region, but the productivity levels are extremely low, mainly because the rearing techniques are not adjusted to the local reality. This statement is reinforced by Santos et al. (2008), who explain that in the 
tropics, ruminant production is traditionaly affected by the ups and downs of forage production, which limits the production and yield of Brazilian herds. They suggest that feed strategies should be implemented to avoid the problems caused by the irregular availability of forage.

Supplementation becomes a necessity for obtaining reasonable levels of animal performance. An appropriate supplementation strategy aims to maximize the consumption and digestibility of the available forage by means of specific nutrients, which allow the animal to consume more dry matter and digest or metabolize forage more efficiently.

Ribeiro (2008) reported that sheep fed on grass and mineral salt showed weight gain of $25 \mathrm{~g}$ /day, while animals receiving feed supplement presented a weight gain of 104 g/day. Costa et al. (2009) observed a daily weight gain of $100 \mathrm{~g}$ when gliricidia leaves were added to sheep diet, while weight increase in the control group amounted only to $40 \mathrm{~g} /$ day.

According to Bernardes et al (2009), strategies should be developed to minimize the impact of forage shortage, in order to reduce slaughter age, improve carcass quality and increase off- season meat supply.

The above mentioned factors and the need of feed supplementation led us to develop the fodder salt technique, which can be used in any environment, because eucotyledons with forage value can be found or cultivated everywhere.

The fodder salt technique has been developed by the Tropical Zootechnical Research Group at the Centro de Ciências Agrárias Ambientais e Biológicas da Universidade Federal do Recôncavo da Bahia (CCAAB/UFRB). Fodder salt is a mixture of mineral salt and ground eudocotyledon forage hay. It is a low-cost technique with high applicability potential for ruminant production in semiarid environments (Oliveira et al., 2010).

The salt controls consumption, for it facilitates the offer of eudicotyledon hay. When added to the mixture, it becomes salty, and the animals ingest it slowyly and repeatedly. This behaviour results in a reduction of feed intake, in less fighting among animals, and allows a better even distribution of feed for all of them. Without a doubt, this technique facilitates feed management and increases herd yield.

There are many vegetal species that can be used for fodder salt preparation, but we would like to emphasize some of them: Manihot esculenta, Crantz; Leucaena leucocephala (Lam.) de Wit.; Gliricidia sepium (Jacq.) Walp; and Manihot pseudoglaziovii Pax \& K. Hoffm. Other species that should be studied are, among others: Caesalpinia pyramidalis Tul.: Cnidoscolus phyllacanthus (Muell. arg.) Pax et K. Hoffman; Bauhinia sp.; Mimosa caesalpiniifolia Benth.; Zyzyphus joazeiro Mart.; Croton conduplicatus; (Prosopis juliflora), Phaseolus firmulus Mart.; Cajanus cajan (L.) Millsp.

The use of forages with high protein content to prepare fodder salt is a good alternative to minimize the problems related to the yearly production variability, such as weight loss and the increase of grazing pressure, which results in pasture degradation and soil erosion. On the other hand, fodder salt increases the animal production levels, as shown by many research studies whose results indicate positive animal performance on pasture and feedlock.

Silva (2005) compared the performance of lambs fed fodder salt prepared with Leucaena sp., Gliricidia sp. and aeral parts of cassava to those fed pangola hay (control group). The author reported that the experimental group presented better performance (109.52, 7.43 and 85.19 g/day, respectively) than the control group (45.24 g/day).

Strada et al. (2006) analyzed Leucaena sp fodder salt diet supplementation on lambs reared on Digitaria decumbens pasture and found higher weight gain in animals supplemented with fodder salt (174.46 g/day) when compared to animals reared on the same pasture, but receiving only mineral salt (137.75 g/day).

Gonçalves et al. (2008) worked with fodder salt from Leucaena sp., cassava aereal parts and wild beans and observed an average daily weight gain of $74.64 \mathrm{~g} ; 85.00$ $\mathrm{g}$ and $48.57 \mathrm{~g}$, respectively. The control animals presented a daily live weight increase of only $20.71 \mathrm{~g}$.

In a recent, still unpublished research on Gliricidia sepium fodder salt (FS), the author found a daily weight gain of $104 \mathrm{~g}$ for animals fed $108 \mathrm{~g}$ FS per day, while controls gained $42 \mathrm{~g}$. There was a feed conversion reduction from 22.51 (control treatment) to 10.37.

These results might be related to a higher crude protein (CP) intake in the diets containing fodder salt. Berchielli et al. (2006) reported that higher CP ingestion maximizes microbial fermentation which might foster the use of neutral detergen fiber NDF and rumen emptying, which in turn stimulates consumption and hence improves animal performance.

\section{Final Considerations}

Some tree and shrub forages have high nutritional value and phytomass production which make them suitable for fodder salt preparation. 
The fodder salt technique has presented very good results in terms of animal performance and can be an alternative for producers.

\section{References}

BERCHIELLI, T.T.; PIRES, A.V.; OLIVEIRA, S.G. Nutrição de ruminantes. Jaboticabal: Funep, 2006. 583p.

BERNARDES, D.F.V.; POMPEU, R.C.F.F.; CÂNDIDO, M.J.D. et al. Comportamento de ovinos confinados e alimentados com torta de mamona destoxificada em substituição ao farelo de soja. In: REUNIÃO ANUAL DA SOCIEDADE BRASILEIRA DE ZOOTECNIA, 46., 2009, Maringá. Anais... Maringá: Sociedade Brasileira de Zootecnia, 2009. p.1-5.

COSTA, B.M.; SANTOS, I.C.V.; OLIVEIRA, G.J.C. et al. Avaliação de folhas de Gliricidia sepium (Jacq.) Walp por ovinos. Archivos de Zootecnia, v.58, p.33-41, 2009.

GIULIETTI, A.M.; BOCAGE NETA, A.L.; CASTRO, A.A.J.F. Diagnóstico da vegetação nativa do bioma da caatinga In: BIODIVERSIDADE DA CAATINGA: ÁREAS E AÇÕES PRIORITÁRIAS PARA A CONSERVAÇÃO, 1., 2004, Brasília. Anais... Brasília: MMA-UFPE, 2004. p.47-90.

GONÇALVES, G.S.; OLIVEIRA, G.J.C.; JAEGER, S.M.P.L. et al. Desempenho de cordeiros alimentados com dietas contendo sal forrageiro de espécies vegetais xerófitas. Revista Brasileira de Zootecnia, v.37, n.12, p.2185-2190, 2008.

OLIVEIRA, G.J.C.; BARBOSA, J.A.; PINHO, M.M.C.A. et al. Nutrição, produtividade e rentabilidade econômica na caprinoovinocultura de corte In: ENCONTRO DE CAPRINOOVINOCULTORES DE CORTE DA BAHIA, 2., 2002, Salvador. Anais... Salvador: ACCOBA, 2002. p.1-15.
OLIVEIRA, G.J.C.; BARBOSA, J.A.; JAEGER, S.M.P.L. et al. Produção de ovinos e caprinos de corte no semi-árido. In: ENCONTRO DE CAPRINO- OVINOCULTORES DE CORTE DA BAHIA, 4., 2004, Salvador. Anais... Salvador: ACCOBA, 2004. p.7-17.

OLIVEIRA, P.A.; OLIVEIRA, G.J.C.; JAEGER, S.M.P.L. Avaliação da capacidade forrageira de espécies arbórea/ arbustivas nativas da micro-região nordeste do estado da Bahia. In: SEMINÁRIO DE PESQUISA DO RECÔNCAVO DA BAHIA, 3., 2009, Cruz das Almas. Anais... Cruz das Almas: UFRB, 2009. p.1-5.

OLIVEIRA, G.J.C.; JAEGER, S.M.P.L.; BAGALDO, A.R. et al. [2010]. Alimentação alternativa para caprinos e ovinos. Disponível em: http://www.montesaltos.com/ Alimentacao_Alternativa_para_Caprinos.pdf. Acesso em: 11/ 2/2010.

RIBEIRO, P.P.O. Níveis de proteína em suplemento múltiplos para ovinos manejados em pastagens de Panicum maximum Jacq cv Aruana na época seca. 2008. 55f. Dissertação (Mestrado em Ciência Animal) - Universidade Federal do Mato Grosso, Cuiabá.

SANTOS, W.S.; CABRAL, L.S.; ZERVOUDAKIS, J.L. et al. Casca de soja em dietas para ovinos. Revista Brasileira de Zootecnia, v.37, n.11, p.2049-2055, 2008.

SILVA, A.M. Consumo de sal forrageiro e desempenho de ovinos deslanados em confinamento. 2005. 51f. Dissertação (Mestrado em Ciências Agrárias) - Escola de Agronomia/ Universidade Federal da Bahia, Cruz das Almas.

STRADA, E.S.O.; OLIVEIRA, G.J.C.; JAEGER, S.M.P.L. et al. Efeito da suplementação com sal forrageiro de leucena (Leucaena leucocephala (LAM) DE WIT) sobre desempenho e características de carcaça de ovinos deslanados em regime de pasto. Magistra, v.18, n.2, p.74-79, 2006. 